\title{
FILM AZ INNOVÁCIÓRÓL: EGY KÖZÉPISKOLÁSOKNAK KÉSZÜLT TANESZKÖZ FEJLESZTÉSÉNEK ÉS BEVEZETÉSÉNEK TAPASZTALATAI
}

\author{
BORSI BALÁZS* - SZEKSZÁRDI JÚLIA** \\ * az Eszterházy Károly Főiskola \\ docense \\ borsi@ektf.hu \\ ** az Osztályfönökök Országos Szakmai Egyesületének \\ elnöke \\ szekja@t-online.hu
}

\begin{abstract}
Kétéves munka keretében, „Neked pörög a dob!” címmel, innovációt oktató, és innovációs attitüdöket erösitö játékfilm készült a 13-18 éves korosztálynak. A film a célközönség diákok számára rendhagyó módon viszonylag sok lexikális jellegü oktatási tartalmat közvetít valóságosnak ható történetbe ágyazva, melynek során családi és baráti konfliktusok keletkeznek és oldódnak meg. Az alkotók szándéka kettös volt: megismertetni az innováció bonyolult jelenségét a diákokkal, s egyben erösiteni azokat az attitüdöket, melyek ahhoz szükségesek, hogy a fiatal korosztály képes legyen újitások megvalósítására. A film fejlesztése során a készitök az oktatási tartalmak kiválasztásához egy kismintás felmérés eredményeit vették figyelembe, a film által kiváltott hatásokat pedig egy attitüdváltást mérö, országos nagymintás felvétel eredményei demonstrálják. Esettanulmányunkban e felmérések eredményeit és a fejlesztési folyamat lényeges mozzanatait mutatjuk be, illetve a film elkészitésén túlmutató, lényegesnek itélt tapasztalatainkat összegezzük a pedagógiai szakma számára.
\end{abstract}

\section{Oktatástechnológiai újítás, mint közszféra-innováció}

Az üzleti szektor innovációi régóta az érdeklődés középpontjában állnak, a közszféra - így például az állami dominanciájú (köz)oktatási szektor - innovációiról kevesebbet tudunk. A közszféra innovációja új, illetve korábban más szektorban meglévő ismeret/tudás gyakorlati alkalmazása a közösségi (államháztartási) szektorban, amely jelentösen új megoldás, javitja a hatékonyságot, növeli a jólétet, vagy arra áttételesen pozitívan hat, közvetlen profitcélok nélkül.

A közszféra innovációinak esetében az újítás a közjót szolgáló értéket teremt, azaz keresi annak a módját, hogy „miként lehet az eddigieket másképp csinálva új 
értéket teremteni". ${ }^{1}$ A közszféra innovációinál is hangsúlyos a gyakorlati alkalmazás kritériuma, ugyanakkor az értékteremtés - az üzleti szektor innovációival szemben gazdasági értékként sokkal áttételesebben mérhető, sok esetben közvetlenül nem is hoz létre gazdasági értelemben vett értéket. ${ }^{2}$

A „Neked pörög a dob!”3 címü film olyan közszféra-innováció, amely:

- erősíteni igyekszik az innovatív személyiségre jellemző attitüdöket;

- a drámapedagógia eszköztárát és a korszerü média lehetőségeit kihasználva közvetít oktatási tartalmakat a célközönség (13-18 éves diákok) felé;

- segíteni kívánja az innováció fogalmának jobb megértését.

\section{A taneszköz fejlesztésének keretei}

Mindenekelőtt azt kellett eldöntenünk, hogy milyen innovációkat érdemes bemutatni az adott életkorú diákoknak. Ennek érdekében 2009 szeptemberében 150 potenciális innovációs témáról egy egyszerü kérdőív alkalmazásával kérdeztünk meg 62 diákot (29 fiút és 31 lányt). Úgy véltük ugyanis, hogy nagyobb esélyünk van a tanulók figyelmének felkeltésére, ha az őket leginkább érdeklő témák kerülnek be a filmbe.

Szükség volt továbbá arra, hogy tisztázzuk: milyen attitüdök jellemzik az innovatív személyiséget. A filmnek ugyanis ezen attitüdök megalapozását kellett szolgálnia. Ugyanezen attitüdök szintjének megállapítására dolgoztunk ki egy viszonylag nagy mintán alkalmazott mérőeszközt is. Munkacsoportunk álláspontja szerint az innovatív személyiség jellemzői a következők:

1. Pozitívan és személyesen viszonyul az innovációhoz. Mindenki lehet innovátor, hiszen megvalósítható, új és eredeti ötlete bárkinek lehet függetlenül attól, hogy pillanatnyilag mit csinál. A sikeres innováció haszna mindannyiunk javára fordítható.

2. A céltudatosság és a divergens gondolkodás egyensúlyára törekszik. Az innovációhoz szükség van tudatos tervezésre és rugalmasságra, a helyzethez történő igazodásra. Szükség esetén képessé kell válnunk arra, hogy új megoldási módokkal próbálkozzunk. A változások gyorsak, ezek dinamikáját követnünk kell, de nem szabad szem elöl vesztenünk a kitüzött célt.

\footnotetext{
${ }^{1}$ Lásd: http://publicsectorinnovation.bis.gov.uk/information/what-is-innovation Utolsó letöltés: 2010. április 20 .

${ }^{2}$ Az áttételes, hosszú távú gazdasági hatások ugyanakkor jelentősek is lehetnek.

${ }^{3}$ Rendező: Borbás Tamás. A „Neked pörög a dob!” film az UTANPOT projekt keretében jött létre. Az UTANPOT projektet az Innova Észak-Alföld Regionális Innovációs Ügynökség Non-Profit Kft., a GKI Gazdaságkutató Zrt., az Osztályfönökök Országos Szakmai Egyesülete (OFOE) és az InnoEx Kft. munkatársai a Nemzeti Kutatási és Technológiai Hivatal támogatásával valósították meg.
} 
3. Képes felelösen dönteni. A felelös döntés feltételezi, hogy tisztában vagyunk a belső és külső lehetőségeinkkel, képesek vagyunk arra, hogy mérlegeljük a lehetséges következményeket, és ezek tudatában döntünk.

4. Szükség esetén vállalja a kockázatokat. A döntéshozatal óhatatlanul kockázatokkal jár. Ezek vállalásához pedig nélkülözhetetlen a bátorság, az esetleg kellemetlen következmények vállalására való készség.

5. Tudatában van annak, hogy akár a hobbi tevékenységböl is eredhet sikeres innováció. A hobbi iránti személyes elköteleződés, fokozott érdeklődés, energiaforrást jelenthet a megújító tevékenységhez, megfelelő elszántság és kedvező körülmények között akár üzlet is lehet belőle. Ilyenkor esély adódik arra, hogy a kellemeset összekössük a hasznossal.

6. Kész és képes az együttmüködésre. A sikeres innovációnak feltétele az együttmüködésre való hajlandóság. Nagyobb a valószínüsége az eredményességnek, ha többen összesítik erőiket, megosztják a munkát, és együtt dolgoznak egy közös cél érdekében. A siker akkor teljes, ha nem marad zárt körben, ha sikerül támogatókat találni az ötletek hasznosításához, és segítséget a szükséges feltételek megteremtéséhez.

7. Felismeri, hogy a reál és humán területen egyaránt van lehetöség. Aktuális probléma jelenleg a reálterületek iránti érdektelenség, ami a felsőoktatási intézményekbe való jelentkezések arányszámaiból is kiderül. Pedig a sikeres innovációk jelentős része a reáltantárgyakhoz kapcsolódik. (Természetesen a humán diszciplínák területén is létezik innovációs lehetőség.)

8. Vállalkozásra való készség és képesség. Ez a tartalmi elem magában foglalja a korábban említetteket: felelősség- és kockázatvállalás, kezdeményezőkészség, céltudatosság és rugalmas gondolkodás, kooperáció stb. A vállalkozó képes mindezeket konkrét tevékenysége során érvényesíteni.

9. Önbizalom, az önmenedzseléshez szükséges kompetenciák. Reális önismeret, pozitív énkép, egészséges önbizalom, önérvényesítő képesség nélkül nincs esélye a sikeres innovációnak.

A továbbiakban elsőként az oktatási tartalmak kiválasztását megalapozó felvétel eredményeit, és a taneszköz fejlesztésére gyakorolt hatásait ismertetjük, majd az attitűdváltást demonstráló felvétel adatainak elemzését ismertetjük.

\section{A 150 innovációs témát tartalmazó témalista szúkítése a film céljaira}

A diákokat megkérdeztük, hogy mennyire új és mennyire érdekes számukra az adott téma - aminek megnevezését és rövid leírását kapták meg. A válaszadó diákok ugyan nem reprezentálják sem életkor, sem régiók szerint az ország középiskolás diákjait, ám a válaszok számossága miatt az eredmények a film forgatókönyvét megalapozó történet kidolgozásához érdemi információkkal szolgáltak. 
A fiatalok sokkal kritikusabban szemlélték az innovációs témajavaslatokat, mint ahogyan azt előzetesen vártuk. ${ }^{4} \mathrm{~A}$ fiú diákok kicsit negatívabban viszonyultak a témák újdonságtartalmához és érdekességéhez, mint a lányok.

1. táblázat: Az UTANPOT három témacsoportjában a vélemények átlagai (GKIOFOE felmérés, 2009. szeptember)

\begin{tabular}{|l|c|c|c|c|}
\hline & $\begin{array}{c}\text { Lányok } \\
(N=31)\end{array}$ & $\begin{array}{c}\text { Fiúk } \\
(N=29)\end{array}$ & $\begin{array}{c}\text { Diákok összesen } \\
(N=62)\end{array}$ & $\begin{array}{c}\text { Tanárok } \\
(N=9)\end{array}$ \\
\hline \multicolumn{5}{|c|}{ 1. Az innováció iránti érdeklödés felkeltésére alkalmas témák } \\
\hline újdonság & 2,47 & 2,36 & 2,43 & n. a. \\
\hline érdekesség & 3,41 & 3,09 & 3,25 & 3,19 \\
\hline \multicolumn{5}{|c|}{ 2. Az innováció és társadalom összefüggéseire irányuló témák } \\
\hline újdonság & 2,76 & 2,48 & 2,64 & n. a. \\
\hline érdekesség & 3,21 & 2,95 & 3,1 & 3,46 \\
\hline \multicolumn{5}{|c|}{ 3. A magyarországi innovációkkal foglalkozó témák } \\
\hline újdonság & 2,86 & 2,63 & 2,75 & n. a. \\
\hline érdekesség & 2,94 & 2,81 & 2,89 & 2,79 \\
\hline
\end{tabular}

Megjegyzés: a válaszadók 1-től 5-ig terjedő skálán osztályoztak

A diákok az innovációk iránti érdeklődés felkeltésére alkalmasnak gondolt témákat gondolták a legkevésbé, a magyarországi témacsoportot a leginkább újnak. A témák érdekességéről éppen fordítva gondolkodnak: a hazai témák a legkevésbé, az érdeklődés felkeltésére szánt témák a leginkább érdekesek. Ez tulajdonképpen nem meglepő, hiszen:

1. az első témacsoportot eleve a diákok számára érdekesnek vélt témákból állítottuk össze, és nyilván ezek között kevesebb a számukra új téma;

2. az innovációkat társadalmi méretekben bemutató innovációkról (például a környezetvédelemhez kapcsolódókról) már sokan hallhattak, és ezek iránt feltételezhetően egy bizonyos fokú érzékenység is kialakulhatott bennük.

3. a bemutatásra szánt magyar innovációk nagy része nem igazán ismert (ilyen értelemben új a diákok számára). Gyakran tekintik ezeket érdekteleneknek, mert nem érzik, hogy közük van hozzá.

A fenti általános összefüggések igen jelentős szóródás mellett adódtak (minden témajavaslat kapott 1 -es és 5-ös értékeket egyaránt), ezért a film fejlesztéséhez a témacsoportokon belüli elemzést is elvégeztük (lásd később).

\footnotetext{
${ }^{4}$ Elméletileg persze vigasztalhatjuk magunkat azzal, hogy a 3 körül szóródó átlagértékek miatt jó eséllyel szólítjuk meg az „átlagos” diákot.
} 
Megkérdeztünk néhány pedagógust is a témajavaslatokról. Ami a témák érdekességét illeti, a pedagógus véleménye az ,innováció és társadalom” témacsoportban érdemben kedvezőbbnek tünik a diákok válaszainál. Ez az eltérés félrevezető is lehet részben a kis mintaelemszám miatt. Befolyásolhatja az eredményt az is, hogy az átlagnál eleve lelkesebb, az újításokra fogékonyabb pedagógusokat vontunk be a munkába. A 150 témajavaslatot a pedagógusok általában alkalmasnak tartották az adott korosztály számára.

Mivel a film első részével az érdeklődés felkeltése, a továbbiakkal pedig az érdeklődés fenntartása volt a célunk - a továbbiakban az érdekesség szerinti diákrangsorokból indultunk ki. ${ }^{5}$ Akadtak nemek szerinti különbségek is, melyekre a taneszköz-fejlesztő munka során tekintettel kellett lennünk. Ezért a nemek szerinti bontásra is ügyeltünk.

Az alábbi táblázat a megkérdezett diákok számára legérdekesebbnek bizonyult 10 témát tartalmazza az „innováció iránti érdeklődés felkeltése” témacsoportból. A csillaggal jelölt esetekben a fiú és lánydiákok között jelentős véleménybeli különbségek vannak, amiket az úgynevezett egymintás t-próba is igazol.

2. táblázat: A 10 leginkább érdekes téma átlagos értékelése az „innováció iránti érdeklődés felkeltése" témacsoportban (GKI-OFOE felmérés, 2009. szeptember)

\begin{tabular}{|l|c|c|c|c|c|c|}
\hline \multirow{2}{*}{} & \multicolumn{3}{|c|}{ ÚJDONSÁG } & \multicolumn{3}{c|}{ ÉRDEKESSÉG } \\
\cline { 2 - 7 } & $\begin{array}{c}\text { Lányok } \\
(N=31)\end{array}$ & $\begin{array}{c}\text { Fiúk } \\
(N=29)\end{array}$ & $\begin{array}{c}\text { Diákok } \\
\text { összesen } \\
(N=62)\end{array}$ & $\begin{array}{c}\text { Lányok } \\
(N=31)\end{array}$ & $\begin{array}{c}\text { Fiúk } \\
(N=29)\end{array}$ & $\begin{array}{c}\text { Diákok } \\
\text { összesen } \\
(N=62)\end{array}$ \\
\hline youtube & 2,35 & 2,52 & 2,44 & 4,48 & 4,52 & 4,48 \\
\hline google & 2 & 2,1 & 2,05 & 4,1 & 4,21 & 4,15 \\
\hline Pimp My Ride & 2,81 & 2,76 & 2,79 & $3,71^{*}$ & $4,38^{*}$ & 4,03 \\
\hline hibrid autó & 3,06 & 3,17 & 3,15 & 3,9 & 4,07 & 4,02 \\
\hline i-phone & 2,65 & 2,41 & 2,56 & $4,32^{*}$ & $3,45^{*}$ & 3,92 \\
\hline Multiplex mozi & 2,35 & 2,41 & 2,39 & 4 & 3,66 & 3,82 \\
\hline South Park & 2,42 & 2,48 & 2,47 & $3,29 *$ & $4,34^{*}$ & 3,77 \\
\hline arcfelismerés & 3,06 & 2,93 & 2,98 & 4,32 & 3,14 & 3,71 \\
\hline digitális fénykép & 2,42 & 2,38 & 2,39 & 3,84 & 3,48 & 3,68 \\
\hline aibo & 3,65 & 3,45 & 3,52 & 3,58 & 3,83 & 3,63 \\
\hline
\end{tabular}

* 95\%-os szignifikanciaszinten jelentős különbség a nemek szerint Megjegyzés: a válaszadók 1-től 5-ig terjedő skálán osztályoztak

\footnotetext{
${ }^{5}$ Ahogy említettük, háromszor 20 perces film elkészítése volt a célunk, hogy a 45 perces tanórák keretében jól feldolgozhatóak legyenek. Az elemzés természetesen az újdonság dimenzió mentén is elvégezhető lett volna, ám a filmekhez hasznosabbnak ítéltük az érdekesség alapján történő elemzést.
} 
Ha a nemenkénti toplistákat nézzük, a lányoknál az első tízbe kerül a WII Nintento konzol, az SMS/Smiley, a BUG interaktív ékszer, a wakeboard (!) és a pattanás elleni szerek, a fiúk toplistájára pedig a torrent, a fémporos autómotor, és a festékszóró patron.

Ugyanezt az elemzést elvégeztük a diákok által összességében legkevésbé érdekesnek gondolt témák esetében is. Többek között azt tapasztaltuk, hogy egyes, az összes diák által unalmasnak gondolt témákat (pl. epillátor, körömlakk) a lányátlagok a mezőny érdekesebb, felső harmadába sorolták - azaz a vélemények nemek szerint szóródása igen jelentős. ${ }^{6}$ A nemek szerinti, legkevésbé érdekesnek gondolt témakörök igazolják ezt a várakozást (dőlt betüvel jelöltük az összesített negatív toplistával és a nemenkénti listákkal is egyező témákat. Ezeket nem is szerepeltettük a filmekben.)

1. A lányok által legkevésbé érdekesnek gondolt témák a következők: hajszáritó, vírusmarketing, vulkanizálás (gumióvszer), High School Musical, post-it, gitárerősítők, fémporos autómotor, torrent, sátor+hálózsák, elektromos gitár.

2. A fiúk által legkevésbé érdekesnek gondolt témák: színes körömlakk, hajszáritó, High School Musical, epillátor, post-it, szőlőzsír, hajfesték, melltartó, Gillian Lynne, virusmarketing.

A lányok által legkevésbé érdekesnek tartott témák közül kettő (torrent, fémporos autómotor) szerepel a fiúk leginkább érdekesnek tartott témalistáján is. Mindezek alapján sejthettük, hogy a film céljaira mik a leginkább érdeklődésre számot tartó témák, de az is biztos volt, hogy a fiús, illetve lányos témák arányára ügyelni kellett az oktatási tartalmak kiválasztásánál. Ezért az egyes témákról alkotott vélemények hisztogramjait esetről esetre is megvizsgáltuk. Az alábbi ábrák a High School Musical és a hibrid autók esetét szemléltetik.

\footnotetext{
${ }^{6} \mathrm{Pl}$. ugyanez fordítva is igaz a vulkanizálás / gumióvszer témára is, azaz ez a téma a fiúk számára érdekesebb.
} 


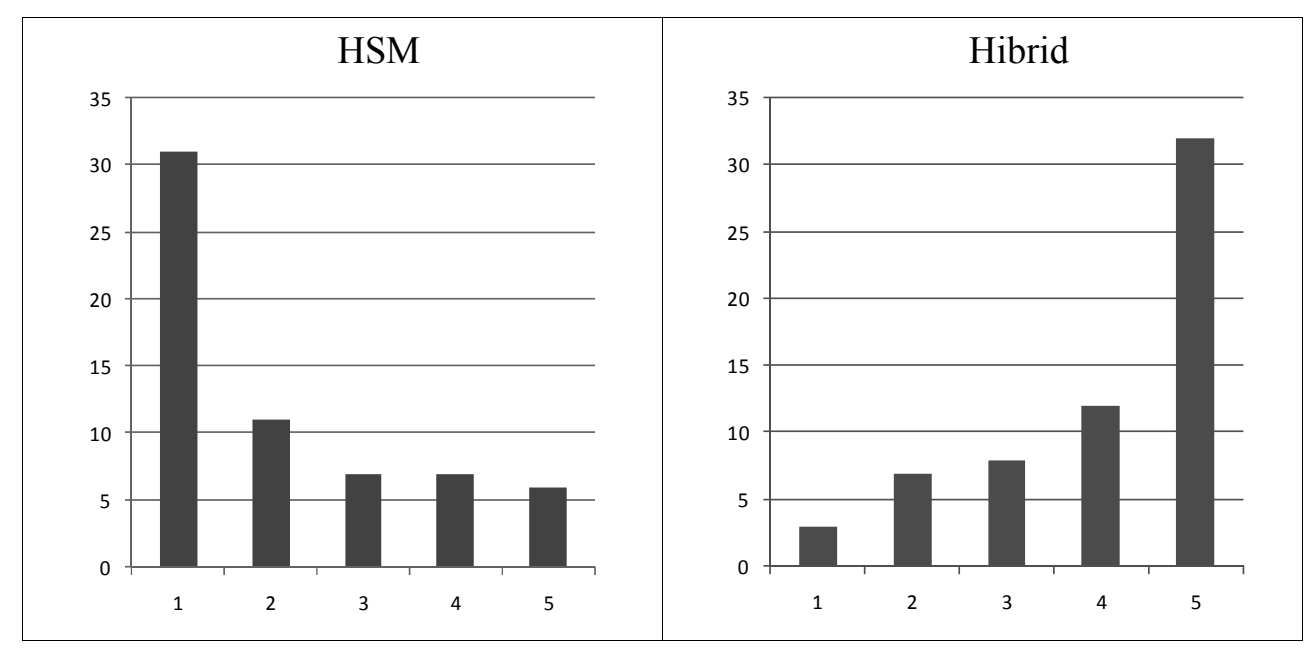

1. ábra: A High School Musical és a hibrid autó, mint témajavaslat érdekességének osztályzatai a diákok körében (a darabszámok eloszlása, N=62) (GKI-OFOE felmérés, 2009. szeptember) Megjegyzés: a válaszadók 1-töl 5-ig terjedő skálán osztályoztak

Az ábrákból látható, hogy a High School Musical feltehetőleg unalmas, a hibrid autó pedig feltehetőleg érdekes a fiúk és a lányok körében egyaránt, azaz az egyiket nem, a másikat pedig érdemesnek tünt beépíteni a filmbe. ${ }^{7}$ A vélemények a gyakorisági adatait valamennyi témajavaslat esetében az érdekesség és az újdonság dimenziókra egyaránt elöállítottuk - nemenként is és összesen is.

A fentiekben jelzett, részletes elemzéseket a további két témacsoport esetében is elvégeztük. Az innováció és társadalom összefüggéseire irányuló témák esetében a következöket tapasztaltuk:

- Kitűnt az infokom technológiákkal kapcsolatos érdeklődés, illetve érdekesnek találtuk, hogy egyes kifejezetten fiúsnak gondolt témáknál nem volt különbség a nemek szerinti csoportok átlagaiban (pl. repülőgép-irányító rendszerek).

- Ebben a témacsoportban is létezik a fiú- és a lányvélekedések között eltérés, viszont a legérdekesebbnek talált témák között ez valamivel kisebbnek látszik, mint az érdeklődés felkeltésére szánt témák esetében. A nemenkénti toplisták is kevésbé térnek el az átlagostól.

- A legkevésbé érdekes témák esetében is kisebb a fiú-lány átlagok közötti eltérés, mint az első témacsoportnál. A legkevésbé érdekesnek vélt témák esetében - a konténeres szállítás és a fapados légijáratok kivételével -

\footnotetext{
${ }^{7}$ Végül a Solo/Duo magyar fejlesztésủ kisautó került be a forgatókönyvbe.
} 
megfigyelhető az is, hogy az újdonságérték magasabb osztályzatokat kapott, mint az érdekesség: ebben a témacsoportban feltehetően több volt a diákok számára ismeretlen témajavaslat.

A gyakoriságok eloszlását szemléltető hisztogramok ebben a témacsoportban gyakran kevésbé segítettek minket, mivel az átlagok mögött megjelenő vélekedések nem mindig markánsak.

A magyarországi innovációkkal foglalkozó témákkal kapcsolatban a következőket tapasztaltuk:

- Ennek a témacsoportnak az érdekességre vonatkozó osztályzatai érdemben gyengébbek voltak az első témacsoportnál.

- A témacsoport érdekes témái körében ismét felerősödnek a különbségek a lányok és a fiúk között.

- A kevésbé érdekes témák esetében a nemek szerinti különbségek szinte eltűnnek: mindössze 2 esetben tértek el jelentősen a fiú- és lányvélemények.

Ugyanakkor, ha a hisztogramok alapján kell döntést hozni a filmbe bekerülésről, nem könnyü a dolgunk még az érdekesnek talált magyar témák esetében sem. A grafikonok a Nav'n Go témajavaslat fiúk és lányok általi értékelését mutatják. Az érdekesség átlagos értékelése a témacsoporton belül viszonylag kedvező, ám a lányok bizonytalanok, és a fiúk válaszai sem igazán meggyőzőek.

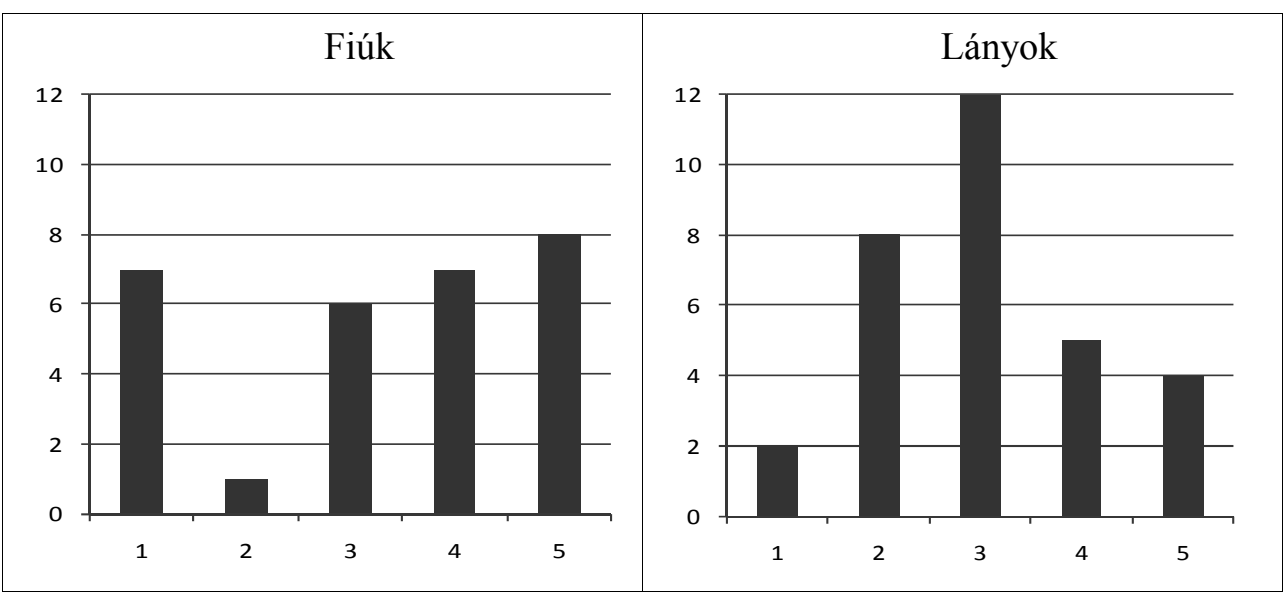

2. ábra: A Nav 'n Go, mint témajavaslat érdekességének osztályzatai a fiúk és a lányok körében (a darabszámok eloszlása, N=29 illetve 31)

(GKI-OFOE felmérés, 2009. szeptember)

Megjegyzés: a válaszadók 1-töl 5-ig terjedő skálán osztályoztak 
Annak érdekében, hogy a témacsoport-besorolásoktól függetlenül is át tudjuk tekinteni a témajavaslatokra adott diák-osztályzatokat, többváltozós statisztikai elemzést is végeztünk. A klaszteranalízist 4 változó segítségével hajtottuk végre: a 150 témajavaslathoz figyelembe vettük az újdonságra és az érdekességre adott osztályzatok átlagait - külön a fiú és külön a lány diákok esetében - azaz a 150 témajavaslatot a 4 dimenziós matematikai térben rendeztük el úgy, hogy a négy változó alapján az egymáshoz közel álló témajavaslatokat egy csoportba soroljuk. Az úgynevezett k-középpontú klaszterelemzésben mi mondhatjuk meg, hogy hány csoport létrehozása kívánatos. Kísérletezve a k=4, 5, 6, 7, 8 esetekkel, a legstabilabb csoportosítás a $\mathrm{k}=6$ esetben adódott. Ez sem volt megnyugtatóan stabil, ami megerősíti, hogy a válaszadó diákok véleményében volt bizonytalanság. Ugyanakkor a klaszterelemzés nagyjából tükrözte a korábban bemutatottakat. Bár egyes esetekben az intuícióra is szükség volt, a filmbe kerülő oktatási tartalmak kiválasztását a felmérés hatékonyan segítette.

\section{A felmérési eredmények hasznosítása a forgatókönyvek készítése során}

Említettük, hogy a diákok az infokom témák iránt érdeklődőek: valóban, a 2010-es évek Magyarországán a tizenévesek a digitális média elsőszámú fogyasztói. A filmben a tinédzser szereplők körül ott van a korosztályukat meghatározó digitális világ: a mobiltelefon segítotársukká válik, és az internet vagy a számítógép nélkül nem csupán az iskolai feladat megoldása elképzelhetetlen. Konkrét innovációs oktatási tartalomként jelenik meg ezért az mp3 lejátszó, az internet fejlődése, a web2 jelenség.

A film természetesen az iskola világában játszódik, és ahogy említettük, a diákok által könnyen átélhető konfliktusokat mutat be. A föszereplö Zoli azt a feladatot kapja az iskolában, hogy írjon egy esszét az innovációról, s az esszé a film végére el is készül. A történet dinamikáját a konfliktusok adják, amelyek Zoli körül a feladat teljesítése során kialakulnak: a technikatanárnővel (aki nem veszi tudomásul, hogy a külön feladattal időt vesz el egy fontos koncertre való felkészítéstől), az apával (aki a koncerttől történő eltiltást helyezi kilátásba, ha fia nem javítja ki az elégtelent), a barátokkal (akik neheztelnek Zolira a próba elmulasztásáért), a barátnővel, Brigivel (aki úgy érzi: a fiú a zenekar miatt elhanyagolja őt) stb. A problémák azonban sorra megoldódnak.

A történet közben a filmbe ágyazott, jól felismerhető oktatási-ismeretterjesztő tartalmak segítenek ráébreszteni arra, hogy az innováció nem valami elvont dolog, amelynek segítségével a tủzközelben lévők meggazdagodnak (Zoli szavaival a „sok zsét szakítják"), hanem olyan jelenség, aminek eredményeit mindennapi életünk során magunk is élvezhetjük, amihez öntudatlanul is közünk van, illetve a későbbi életünk során személyesen is közünk lehet. Az érdeklődés felkeltésére a már említett mp3 lejátszók mellett a Magellán kerékpár, a körömlakk, a humanoid robot témák bizonyultak alkalmasnak. 
A film alapötletét adó hármas problémakörhöz igazodva bizonyítást nyer az is, hogy az innovációk társadalmi méretekben is jelentősek: a passzív ház, a web2, a shinkansen, a $H P V$ vírus elleni oltás rövid ismertetése és magyarázata ezt a célt szolgálja.

A film alkotói csapata a „Magyarország és az innováció” témacsoportban volt kénytelen leginkább megérzésekre hagyatkozni: miközben a válaszok alapján támaszkodhattunk néhány erösebbnek látszó témára, a nagyfokú bizonytalanság miatt e blokk háttéranyagainak és forgatókönyveinek elkészítése keményebb diónak bizonyult, mint az első két témacsoport esetében. Végül a Szentkirályi ásványviz története, a Fornetti franchise, a Magellán kerékpár fejlesztés, a Diáksziget, egy (fiktív) retro napszemüveg piacra dobása, a Leonar3do, valamint a hellodesign került be a forgatókönyvbe.

\section{Attitűdök erősödése és attitűdváltás: a film hatásai}

A taneszköz fejlesztésének kereteit ismertető fejezetben bemutatott attitüdök országos mérésével az alábbi hipotéziseket kívántuk tesztelni:

- A taneszköz segítségével a fiatalok alaposabban megismerik az innováció fogalmát, belátják jelentőségét a társadalom, a csoportok és az egyének életében.

- Felismerik, hogy valóban közük van hozzá: tehetnek azért, hogy hasznára legyenek szükebb és tágabb környezetüknek, s hogy ök maguk nem csupán haszonélvezői, hanem cselekvő részesei lehetnek bizonyos a megújulást segítő folyamatoknak.

- Ráeszmélnek felelősségükre saját boldogulásukban, és azokra az egyéni lehetőségekre, amelyek önnön kreativitásuk mellett a másokkal való együttmüködésben rejlenek.

- Megbizonyosodnak arról, hogy: Magyarországon is létezik sikeres innovációs tevékenység.

Az attitüdöket egyszerü feleletválasztós, többségében ordinális mérési szintű önkitöltős kérdőíves kérdésekkel vizsgáltuk, felépítése egyszerü volt, és illeszkedett a korcsoporthoz. Két fő részből állt: a kategorizálásra alkalmas háttérváltozókból, illetve a vizsgált attitüdökkel kapcsolatos kérdésekből. Az egyes itemek megítélése egy ötfokozatú Likert skálán történt (lásd a mellékletet). ${ }^{8}$

A mintaválasztásnál törekedtünk a reprezentativitásra, ez azonban, mivel a részvétel önkéntes volt, csak részben sikerülhetett. A vizsgálati eszköz véglegesítése egy pilotvizsgálat és egy fókuszcsoportos megbeszélés tanulságait feldolgozva történt.

A mérést a következő ütemezésben és csoportosításban hajtottuk végre:

- összesen két időpontban történt mérés, 52 iskolából 1308 diáktól gyűjtöttünk össze elemzésre alkalmas kérdőívet;

\footnotetext{
${ }^{8}$ A kérdőívet Hanczár Gergely készítette.
} 
- a diákok egyik csoportja (505 fö) a két mérés között nem nézte meg a filmet, másik csoportja (803 fö) megnézte és feldolgozta a filmet. ${ }^{9}$

A beválás-vizsgálat egyik korlátja, hogy nemcsak a fejlesztett taneszközt, hanem az annak exponálásával kapcsolatos összes járulékos eseményt együtt vizsgálja. Vagyis a meghatározott mérési keretek önmagukban kizárják a taneszköz minösítését, helyette azt az egyébként nagyon érdekes kérdést tudjuk megválaszolni, hogy a taneszköz mindenféle áttételen keresztül érvényesülő közvetett és közvetlen hatása a tanárra, a diákra, a közösségre, az általa indikált párbeszédek mennyiben változtatják a feltételezett attitüdöket.

Az összesen kilenc vizsgálni kívánt attitüdből öt esetében statisztikailag szignifikáns elmozdulás volt tapasztalható. Ezeket az alábbi táblázat összegzi.

3. táblázat: A megváltozott attitüdök átlagai* (GKI - OFOE felmérés, UTANPOT projekt, 2010. július-november)

\begin{tabular}{|c|c|c|c|c|}
\hline & $\begin{array}{c}\text { Filmet nem } \\
\text { megnézök } \\
(N=505)\end{array}$ & $\begin{array}{c}\text { Filmet } \\
\text { megnézök } \\
(N=803)\end{array}$ & $\begin{array}{c}\text { Összes } \\
\text { diák } \\
N=1308\end{array}$ & $\begin{array}{c}\text { Különbség a filmet } \\
\text { megnézők és nem } \\
\text { megnézök között }\end{array}$ \\
\hline \multicolumn{5}{|c|}{ A közöd van az innovációhoz (tool) attitüd átlagai } \\
\hline Első mérés (a) & 3,597 & 3,617 & 3,610 & 0,020 \\
\hline Második mérés (b) & 3,569 & 3,664 & 3,627 & $0,095 * *$ \\
\hline Változás (b-a) & $-0,028$ & 0,046 & 0,018 & $0,075 * *$ \\
\hline \multicolumn{5}{|c|}{ A felelősséggel dönteni váratlan helyzetekben is (strat) attitüd átlagai } \\
\hline Első mérés (a) & 3,090 & 3,066 & 3,075 & $-0,025$ \\
\hline Második mérés (b) & 3,088 & 3,169 & 3,138 & $0,081 * *$ \\
\hline Változás (b-a) & $-0,002$ & 0,103 & 0,062 & $0,105 * *$ \\
\hline \multicolumn{5}{|c|}{ A készség és képesség az együttmüködésre (coop) attitüd átlagai } \\
\hline Első mérés (a) & 3,331 & 3,301 & 3,313 & $-0,029$ \\
\hline Második mérés (b) & 3,287 & 3,342 & 3,320 & $0,055^{* *}$ \\
\hline Változás (b-a) & $-0,044$ & 0,040 & 0,008 & $0,085 * *$ \\
\hline \multicolumn{5}{|c|}{ A vállalkozásra való készség és képesség (biz) attitüd átlagai } \\
\hline Első mérés (a) & 3,059 & 3,108 & 3,089 & 0,049 \\
\hline Második mérés (b) & 3,069 & 3,163 & 3,126 & $0,094 * *$ \\
\hline Változás (b-a) & 0,010 & 0,055 & 0,038 & 0,045 \\
\hline
\end{tabular}

\footnotetext{
${ }^{9}$ A film feldolgozásában a részt vevő pedagógusok teljesen szabad kezet kaptak. Például voltak, akik 3 hét alatt nézték meg a 3 részt, más esetekben egyszerre történt a vetítés stb.
} 


\begin{tabular}{|l|c|c|c|c|}
\hline & $\begin{array}{c}\text { Filmet nem } \\
\text { megnézök } \\
(N=505)\end{array}$ & $\begin{array}{c}\text { Filmet } \\
\text { megnézök } \\
(N=803)\end{array}$ & $\begin{array}{c}\text { Összes } \\
\text { diák } \\
N=1308\end{array}$ & $\begin{array}{c}\text { Különbség a filmet } \\
\text { megnézök és nem } \\
\text { megnézők között }\end{array}$ \\
\hline \multicolumn{2}{|c|}{ Az önbizalom, az önmenedzseléshez szükséges kompetenciák (ego) attitüd átlagai } \\
\hline Első mérés (a) & 3,574 & 3,553 & 3,561 & $-0,021$ \\
\hline Második mérés (b) & 3,516 & 3,617 & 3,578 & $0,101^{* *}$ \\
\hline Változás (b-a) & $-0,058$ & 0,064 & 0,017 & $0,122^{* *}$ \\
\hline
\end{tabular}

* Az attitüd a mellékletben ismertetett állításokból áll össze. Ha a diák egyetértett az állítással, 5-ösre, ha nem, 1-esre értékelte. A táblázat az átlagokat tartalmazza ** 95\%-os szignifikanciaszinten jelentős különbség (független mintás t-próba alapján)

Számunkra külön örvendetes, hogy az attitüdök szintjén a legnagyobb elmozdulás az önmenedzseléshez szükséges kompetenciák terén mutatkozott. A következő ábra azokat az itemeket ábrázolja, amelyek esetében a film elötti és utáni adatok a legnagyobb - minden esetben kedvező irányú - elmozdulást mutatják.

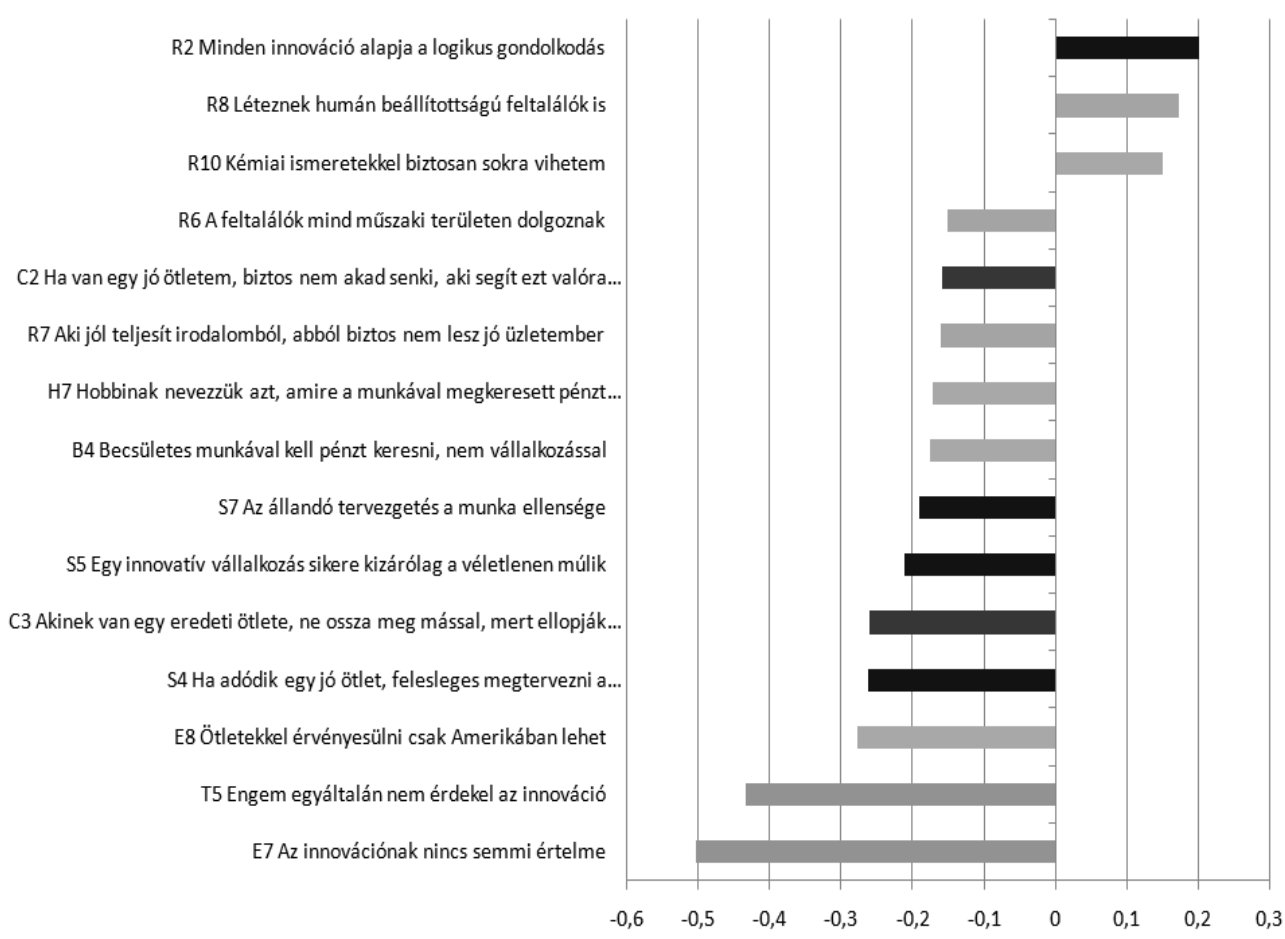

3. ábra: A leginkább megváltozott vélemények $(\mathrm{N}=803)$

(GKI - OFOE felmérés, UTANPOT projekt, 2010. július-november) 
A legfőbb itemenkénti tanulságok szerint a film megtekintését követően:

- Többen hisznek abban, hogy szerepe van a tervezésnek, nem lehet csak a spontaneitásra hagyatkozni, a folyamatokban nem csupán a véletlenek játszanak szerepet (S7, S4, S5, lásd a mellékletet).

- A megkérdezettek nagyobb százalékban hisznek az együttmüködésben, és valamelyest csökkent a bizalmatlanság is $(\mathrm{C} 2, \mathrm{C} 3)$.

- Bizonyíthatóan ,átjött” a filmnek az a fontos üzenete is, hogy hazánkban is lehet boldogulni a jó ötletekkel (E8).

- Felértékelődik a kreativitás szerepe, jelentősége. Csökkent azoknak az aránya, akik a vállalkozást és a becsületes munkát szembeállítják egymással (B4).

- A legnagyobb elmozdulás az innováció megítélésében van (T5, E7), tehát valószínüsíthetően a film felkeltette az érdeklődést az innováció iránt, megerősítette azt, hogy a fiataloknak valóban közük van az innovációhoz, hat az életükre.

A pontos elemzéshez fontos látni a különféle áttételeket. Egy részét elöre sejthettük, más részét szofisztikáltabb felmérésekkel a későbbiekben volna érdemes megvizsgálni. Például egy tanár ma pontosan tudhatja, hogy az innováció fontos része társadalmunknak. Azonban jelenleg sokan azt élhetik meg, hogy nincs eszközük arra, hogy ezzel iskolai keretek között bárhogyan is foglalkozzanak. Iskoláink, tanáraink alapvetően tananyag és tantervszemléletüek. Attitüdökben, kompetenciákban kevesen gondolkodnak. Ha képesek is rá, ritkán rendelik ez alá a céljaikat, inkább csak elemezni tudnak a segítségével. Mindazonáltal a tesztelni kívánt hipotézisek összességében igazolhatónak bizonyultak.

A nem az attitüdméréshez kapcsolódó adatok elemzése alapján elmondható továbbá, hogy bár a diákok kritikusak voltak a filmmel kapcsolatban, a vetítés közvetlen hatásaként:

- csaknem egyharmaduknak lett pár ötlete;

- az új ötlettel rendelkezők bő fele úgy vélte, azonnal hozzá is lát;

- az új ötlettel rendelkezők négyötöde kapott inspirációt, hogy hogyan lásson hozzá;

- a diákok egynegyede szívesen továbbadná a filmet a youtube-on, és hasonló arányban sajnálkoznak, hogy ott még nem elérhető;

- a diákok egynegyede ugyan közömbös maradt, de felét biztosan nem idegesítette a film.

Összességében ezek az arányok is kedvezőnek tekinthetők.

\section{Kvalitatív tantermi tapasztalatok}

A szerzők abban a szerencsés helyzetben vannak, hogy a „Neked pörög a dob!” film mintegy tucatnyi vetítésén vehettek részt, ahol a legváltozatosabb közönség foglalt helyet. Rendelkezésre áll az 52 iskolai vetítés körülményeit és egyes megfi- 
gyeléseket rögzítő dokumentáció, melyet a Regionális Innovációs Ügynökségek munkatársai készítettek el. Az egri Eszterházy Károly Föiskolán föiskolai hallgatók több szemináriumon is látták a filmet. Ezen kívül hasznos visszajelzéseket kaptunk a Budapesti Corvinus Egyetem Vállalatgazdaságtani Intézetétöl is, akiknek munkatársai 2010 októberében a frissen felvett egyetemi hallgatókat ismertették meg a filmmel, szemináriumi munka keretében.

Bár nagyon nehéz a tantermi tapasztalatok összegzése, a következőket állapíthattuk meg:

- Azokban az esetekben, amikor a tanár kötelező feladatként „teljesítette” a vetítésre vonatkozó kérést, gyakrabban találkoztunk kedvezőtlen vélekedésekkel. Ez akár az attitüdméréses vizsgálat eseteinek egynegyedétegyharmadát is érinthette, azaz a kedvező attitüdváltások átlagai lényegesen kedvezőbbek, ha a téma iránt érdeklődő és motivált tanárok mutatják be a filmet és dolgozzák fel a diákokkal.

- Azokban a föiskolai-egyetemi esetekben, amikor a tanárok alkalmasnak itélték a feldolgozást a 13-18 éves célközönségnél idősebb korosztállyal is, kifejezetten kedvezőek a tapasztalatok, bár a hallgatóság rendszerint megjegyezte azt is, hogy érzésük szerint ők már idősek a filmhez.

- Nagyon érdekesek voltak azok a vetítéshez kapcsolt viták, melyeken közgazdász tanárok vettek részt. Közülük a legtöbben jól használhatónak tartották a filmet, és később igényeltek is belőle saját példányt.

- Úgy tapasztaltuk, hogy az átlagosnál lényegesen rosszabb körülmények között élő diákokat is lekötötte a film, ám a feldolgozhatóság esélyeit a mindennapok nehézségei lényegében lehetetlenné teszik. Mivel a magyar középiskolás réteg rendkívül differenciált, a film vélhetően az átlagostól nem nagyon eltérő, illetve a jobb helyzetben levő iskolákban képes érdemi hatást kifejteni.

\section{Összegzés: a taneszköz fejlesztésével kapcsolatos tapasztalatok}

A diákok véleményének figyelembevételével az oktatófilm tartalmának fejlesztése során hasznos segítséget kaptunk arra vonatkozóan, hogy mely témák untatják a diákokat, és melyek azok, amelyekkel valamilyen érdeklődés jó eséllyel megteremthető, amennyiben a filmben feldolgozzuk azokat. Ugyanakkor a vélemények összegyüjtésekor kapott, összességében alacsony osztályzatok, a magyar esetek iránti közömbösség, a társadalmi méretekben jelentős innovációkkal kapcsolatos (negatív) vélekedések mind-mind arra utaltak, hogy szükség van a hasonló az oktatófilmekre: a megcélzott korosztályban folytatni kell az ismeretterjesztő és motiváló munkát.

A filmnézés hatásait vizsgáló országos attitüdmérés eredményei alapján megállapítható, hogy az UTANPOT projekt keretében elkészült taneszköz az innováció iránti attitüd mindhárom komponensére (kognitív, affektív, motorikus) hatást gya- 
korolt. Mélyült és árnyaltabbá vált a tanulókban az innováció fogalma. Érzékelhetően javult az érzelmi beállítódás, és az eddigi tapasztalatok birtokában úgy véljük, hogy a kapcsolódó tevékenységre is nőtt a hajlandóság.

Összességében, elmondható, hogy a „Neked pörög a dob!” film egy viszonylag sikeres kezdeményezés a fiatal korosztály innovációra nevelésében. Mivel azonban sokkal komplexebb kérdésről van szó, mint hogy egyetlen beavatkozással igazi áttörést lehetne elérni, ezt a projektet csupán egy hosszabb fejlesztő tevékenység első állomásának tekinthetjük.

\section{Irodalom}

Allport, G. W. (1979): Az attitüdök. In: Halász László - Hunyady György - Marton Magda (szerk.): Az attitűd pszichológiai kutatásának kérdései. Akadémiai Kiadó, Budapest. 1979. 41-57.

Borsi Balázs, Szekszárdi Júlia (2010): Neked pörög a dob! Útmutató tanároknak a filmek felhasználásához. URL: http://www.osztalyfonok.hu/files/UTANPOTutmutato.pdf

Török Ildikó (2010): Neked pörög a dob. Az Utanpot projekt első tapasztalatai. URL: http://www.osztalyfonok.hu/cikk.php?id=851 


\section{MELLÉKLET}

\section{A kérdő́ívben szereplő itemek tartalmi csoportosításban}

\section{Közöd van az innovációhoz! (tool) attitüd}

(T1) Biztosan nekem is lehet megvalósítható ötletem.

(T2) Lehet, hogy én is egy saját ötletem megvalósításából fogok megélni.

(T3) Nincs kizárva, hogy egy kreatív ötletemből fogok meggazdagodni.

(T4) Az innovációt egyes esetekben az adott helyzet teszi lehetővé.

(T5) Engem egyáltalán nem érdekel az innováció.

(T6) Nem tisztességes az, aki egy ötletből akar meggazdagodni.

(T7) A tisztességes munka és az ötletelés kizárja egymást.

(T8) Egy takarítóból is válhat sikeres vállalatvezető.

(T9) Ha lenne egy jó ötletem, biztosan meg tudnék általa gazdagodni.

\section{Céltartás és megújulni tudás az innováció folyamatában (path) attitüd}

P1 Gyakran találok olyan megoldásokat, amelyek másoknak nem jutnak eszébe.

P2 Ha úgy alakul az életem, bármikor szakmát váltok (bátorság).

P3 Mielőtt kirándulni indulok, pontos útitervet készítek és azt be is tartom.

P4 Anyu akkor is jókat tud fôzni, ha közben észreveszi, hogy valami fontos alkotórész (pl. tejföl) hiányzik.

P5 Szeretek új utakat kipróbálni.

P6 Ha akarnék, tudnék olyan puskát készíteni a dolgozatíráshoz, amit teljesen lehetetlen észrevenni.

P7 Én egészen más módon tanulok, mint a többiek.

\section{Felelösséggel dönteni váratlan helyzetekben is (strat) attitüd}

S1 Kb. százezer forint elég lenne ahhoz, hogy megvalósítsak egy ötletet.

S2 Mielőtt új vállalkozásba kezdenék, tájékozódnék arról, hogy mások hogyan csinálták.

S3 Minden egyes innovatív vállalkozás teljesen más, mint a többi.

S4 Ha adódik egy jó ötlet, felesleges megtervezni a megvalósítást, hiszen nem lehet elöre tudni, hogyan alakulnak a dolgok.

S5 Egy innovatív vállalkozás sikere kizárólag a véletlenen múlik.

S6 Olyan még nem volt, hogy valahogy ne lett volna.

S7 Aki hosszan tervezget, annak nem marad ideje a munkára. 


\section{Esetenként szükség lehet kockázatvállalásra (risk) attitüd}

K1 Nagyon szeretem az igazi kalandokat, akkor is, ha sok viszontagsággal járnak.

K2 Szeretnék egyedül elutazni ismeretlen országokba.

K3 Szívesen lennék katona.

K4 Kockázat nélkül nincs siker.

K5 Ha úgy adódna azt is kibírnám, hogy hajléktalan legyek.

K8 Szeretek úgy öltözni, hogy a felnőttek felháborodjanak.

\section{A hobbi nem csak üres időtöltés (hobbi) attitüd}

H1 A hobbim kapcsán jutott már eszembe olyan dolog, ami másnak még nem.

H2 A saját hobbimban én vagyok a legeslegjobb.

H3 Irigylésre méltóak azok az emberek, akik a hobbijukból tudnak megélni.

H4 A hobbijukból csak az ingyenélők tudnak megélni.

H5 A hobbi és a munka nem egyeztethetö össze.

H6 A hobbi lényege az, hogy nem munka, hanem szórakozás.

H7 Hobbinak nevezzük azt, amire a munkával megkeresett pénzt költhetjük.

H8 Nekem egyáltalán nincs is hobbim.

\section{Készség és képesség az együttmüködésre (coop) attitüd}

C1 Ha adódik egy igazán eredeti ötletem, azt egyedül is képes vagyok megvalósítani.

C2 Ha van egy jó ötletem, biztos nem akad senki, aki segít azt valóra váltani.

C3 Akinek van egy eredeti ötlete, ne ossza meg mással, mert ellopják tőle!

C4 Az ötlet a lényeg. Ha az már megvan, segítség nélkül is boldogulhatunk.

C5 Megfelelő támogatás nélkül a legjobb ötlet is elkallódik.

C6 Egy vállalkozás sikere leginkább az együttmüködésen múlik.

C7 Ha két barát összefog, bármit meg tudnak valósítani.

\section{A reál tantárgyak, területek kapcsolódása az innovációhoz (real) attitüd}

R1 Aki nem ismeri a matematikai alapmüveleteket, az nem lehet jó vállalkozó.

R2 Minden innováció alapja a logikus gondolkodás.

R3 Matematika és fizika nélkül gondolkodni sem tanul meg az ember.

R4 A legtöbb innováció müszaki-technológiai területen születik.

R5 A biológia jó ismerete nem segít meggazdagodni.

R6 A feltalálók mind müszaki területen dolgoznak.

R9 Aki nincs tisztában a számítástechnika elméleti alapjaival, az nem boldogul.

R10 Kémiai ismeretekkel biztosan sokra vihetem. 
8. A vállalkozásra való készség és képesség (biz) attitüd

B1 Egy jó ötletet könnyü eladni.

B2 Sok olyan ember van, akinek jó ötletekből sikerült meggazdagodni.

B3 Ha lenne egy jó ötletem, megmutatnám egy üzletembernek, és rábíznám a megvalósítást.

B4 Becsületes munkával kell pénzt keresni, nem vállalkozással.

B5 Aki vállalkozik, könnyen belebukhat.

B6 A vállalkozás szerencsejáték.

9. Önbizalom, az önmenedzseléshez szükséges kompetenciák (ego) attitüd

E1 Volt már zseniálisan jó ötletem.

E2 Ha én vállalkozó lennék, jobban végezném a dolgomat, mint mások.

E3 Tudok úgy puskázni, hogy a tanár ne vegye észre.

E4 Ha akarnám, egész jó vállalkozó lehetne belőlem.

E5 Minden adottságom megvan ahhoz, hogy sikeres üzletember legyek.

E6 A siker általában nem a tehetségen múlik, hanem kitartáson.

E7 Az innovációnak nincs semmi értelme.

E8 Ötletekkel érvényesülni csak Amerikában lehet. 